\title{
OCEANA
}

\section{Casting a Wider Net: More Action Needed to Stop Seafood Fraud in the United States}

\author{
March 2019 \\ Authors: Dr. Kimberly Warner, Whitney Roberts, Patrick Mustain, Beth Lowell and Marissa \\ Swain
}

DOI: $10.31230 / o s f . i o / s b m 8 h$

\section{Executive Summary}

If you order red snapper at a restaurant, you should get red snapper. If you found out it was something else, you would rightly be angry. But what if you also found out that the fish you ate may have been caught illegally, or had been imported when you thought it was caught locally? Seafood mislabeling can also cover up fish caught or raised with fishing or farming methods that can harm the environment. Overfished species can be labeled as more abundant varieties and cheaper offerings can be sold as more expensive ones to fetch a higher price. Seafood fraud cheats consumers and hurts fishermen and businesses that play by the rules.

To highlight and address these problems, Oceana has investigated seafood fraud since 2010, testing more than 1,500 samples for DNA identification. In these studies, Oceana found roughly one-third of samples tested were mislabeled. Oceana brought this issue to the public's attention and urged the government to act.

In 2014, the federal government established the Task Force on Combating Illegal, Unreported and Unregulated (IUU) Fishing and Seafood Fraud. The task force issued recommendations that ultimately led to the establishment of the Seafood Import Monitoring Program (SIMP) in 2018. SIMP requires catch reporting and traceability for 13 types of imported seafood at risk of seafood fraud and illegal fishing. However, the traceability requirements end at the U.S. border.

To expose gaps in the current policy, Oceana launched a nationwide investigation of some popular seafood types not covered by the program. Oceana employees and volunteers collected more than 400 samples from over 250 locations in 24 states and the District of Columbia, including restaurants, large grocery stores and smaller markets. Despite the new program, Oceana discovered seafood mislabeling remains a problem in the United States.

Key Findings:

- One out of every 5 of the 449 fish tested (21 percent) were mislabeled.

- Some of the most commonly collected seafood types in the study, sea bass and snapper, had the highest rates of mislabeling (55 and 42 percent, respectively).

- One out of 3 establishments visited sold at least one item of mislabeled seafood.

- Seafood was more frequently mislabeled at restaurants and smaller markets than at the larger chain grocery stores. 


\section{OCEANA}

- Some popular regional favorites, such as local Great Lakes yellow perch, were found to be imported fish like zander, a species from Europe and Asia.

- Some depleted fish species that are not sustainably caught were labeled and sold as more sustainable fish (e.g. overfished Atlantic halibut sold as more abundant Pacific halibut).

Seafood fraud remains an issue, including for many species that are not covered by the federal traceability regulations. Oceana recommends that those rules be expanded, requiring catch documentation detailing when, where and how a fish was caught or farmed for all seafood. This and other important information should follow the fish through every step of the supply chain from where it was caught to the final point of sale. Consumers should be provided with more information about the seafood they eat, including exactly which species they purchased. This is the only way U.S. consumers can know that their seafood is safe, legally caught and honestly labeled.

\section{$\underline{\text { Introduction }}$}

U.S. seafood consumption has been trending up, with consumption in 2017 at an all-time high. ${ }^{1}$ But consumers are not just eating more, they are also diversifying beyond more popular seafood types like shrimp, salmon and tuna. With more species flooding the seafood market, improved labeling regulations and traceability are crucial to ensure that what ends up on consumers' plates is actually what they ordered. Unfortunately, opportunities to mislabel products exist throughout the murky supply chain, potentially misleading or confusing consumers about the seafood they purchase.

Seafood fraud encompasses any activity that misrepresents the fish purchased - from mislabeling seafood and falsifying documents, to adding too much ice to packaging. Oceana's focus on species substitution includes a 2013 nationwide study and a global review of seafood fraud, ${ }^{2,3}$ which helped increase public awareness of the problem. The U.S. government took action, forming an interagency task force responsible for combating illegal fishing and seafood fraud. ${ }^{4}$ In January 2018, the federal government implemented SIMP, a risk-based traceability program requiring, for the first time, that some imported seafood be subject to the same catch reporting requirements as domestically caught fish, and requiring traceability from the point of catch or farm to the U.S. border. $^{5}$

However, SIMP only includes 13 types of seafood at risk of fraud and illegal fishing, and only applies to imported seafood (Appendix A). Traceability requirements also end the U.S. border, leaving products untraced throughout the U.S. supply chain. To highlight the problem of seafood fraud beyond those 13 types, Oceana conducted another nationwide study focused on seafood not included in SIMP. 


\section{OCEANA}

\section{Overall Results}

Between March and August 2018, Oceana employees and volunteers collected seafood samples from 287 seafood restaurants, grocery stores and seafood markets in 27 cities across 24 states and the District of Columbia and submitted them to a laboratory for DNA analysis. Samples from 10 of the establishments were not viable for DNA analysis, so samples were successfully analyzed from 277 establishments. Ninety-four of the 449 successfully analyzed samples, or 21 percent, were mislabeled. A mislabeling rate of 1 in 5 is similar to what Oceana found in its 2016 global review of more than 200 seafood fraud studies, ${ }^{1}$ but lower than the rate found in Oceana's previous U.S. nationwide survey that included a wider range of species, many of which are currently included in SIMP (33 percent). ${ }^{3}$

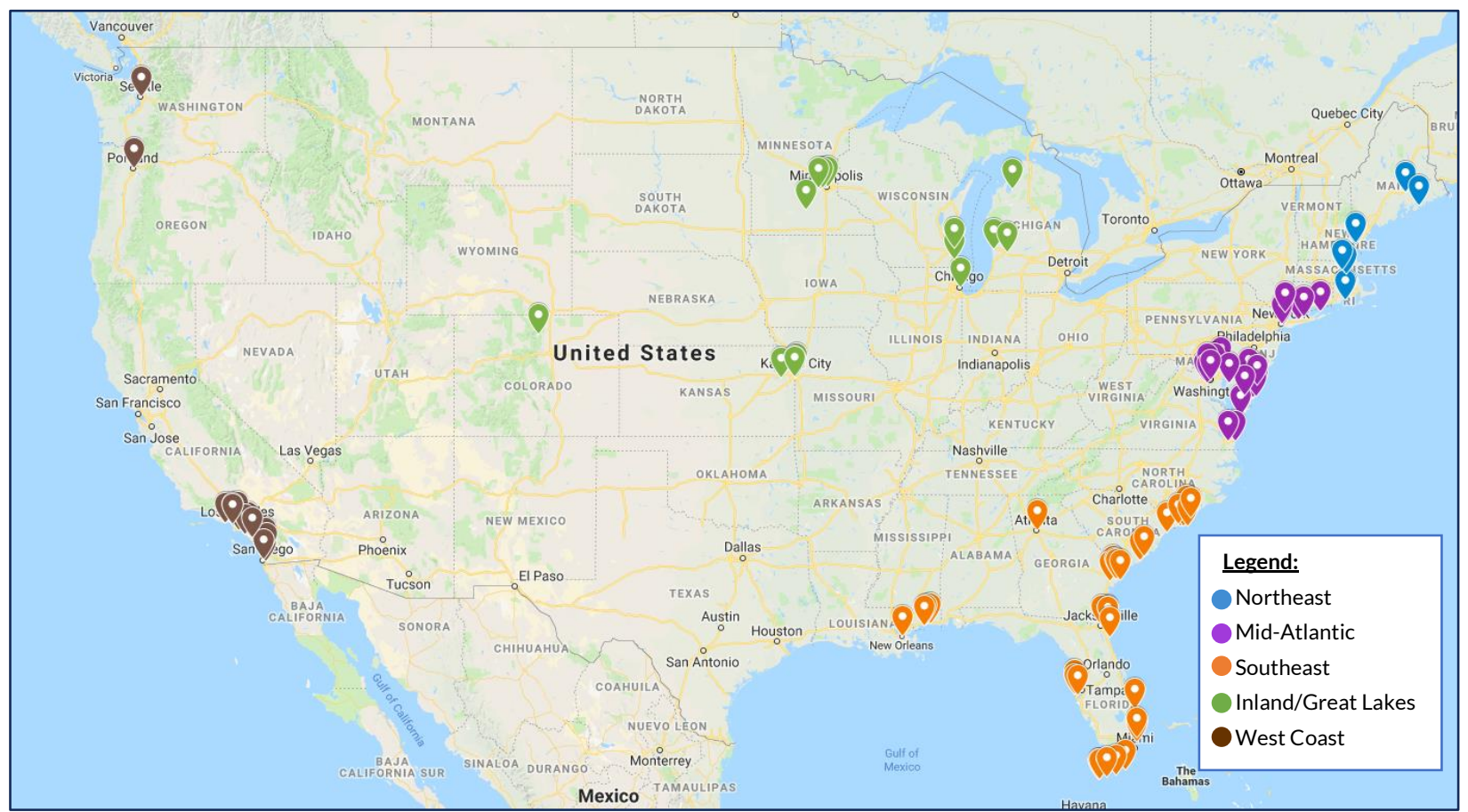

Figure 1. Seafood sample collection locations, color-coded by region. See Appendix C for a full list of states where samples were collected for each region.

The Food and Drug Administration (FDA) Seafood List establishes guidelines for naming seafood products and provides the acceptable market names, scientific names and common names for more than 1,800 species. $^{6}$ The FDA Seafood List also contains vernacular names for some species, which are names that may only be known locally. The FDA stresses that vernacular names are not acceptable market names and using them may be considered misbranding. ${ }^{6}$ Oceana considered a sample to be mislabeled if the seafood identified did not match the label (e.g. tilapia sold as snapper) or did not follow FDA Seafood List's guidelines (e.g. Patagonia toothfish sold as "seabass" instead of "toothfish" or "Chilean seabass"). Further detail about the methods used can be found in Appendix B.

Among the 29 different types of seafood collected, Oceana identified 83 different species by DNA analysis. For example, 20 different species were sold under the generic name "snapper," including 11 species of snapper, and other species like tilapia, bonnetmouth and Indian Ocean spiny halibut. 


\section{OCEANA}

Thirty-four percent (97/277) of the establishments visited sold mislabeled seafood. Oceana bought seafood from a variety of high and low-priced restaurants as well as small markets and large-chain grocery stores. Consistent with past analyses, samples obtained from restaurants showed a higher mislabeling rate (26 percent of 227) than grocery stores and markets combined (16 percent of 222). However, the mislabeling rate for small markets, including seafood markets (24 percent of 75), was twice the rate of large-chain grocery stores (12 percent of 147), which are required to follow Country of Origin Labeling $(\mathrm{COOL})$ requirements. This finding is consistent with past research. ${ }^{7} \mathrm{COOL}$ requires that most large grocery stores (those selling more than $\$ 230,000$ annually in fruits and vegetables) clearly identify the country of origin on some seafood products as well as information on production method (wild or farmed) and whether the seafood was previously frozen. Restaurants and certain other retailers (e.g. fish markets, small establishments) are exempt. ${ }^{8}$

Mislabeling rates also appeared to vary across regions. Although the types of fish and numbers of samples collected were not equally distributed among regions, samples collected in the MidAtlantic region had the highest rate of mislabeling at 31 percent (32/104), while samples collected in the Northeast had the lowest rate, at 8 percent (4/45). See Appendix C for a list of states where mislabeled samples were collected.

Of the most commonly collected seafood types in our investigation, samples sold as sea bass and snapper had the highest rates of mislabeling ( 55 and 42 percent, respectively), followed by halibut (26 percent), flounder (22 percent), sole (21 percent), lobster (8 percent), catfish (7 percent) and scallop (6 percent) (Figure 2). At least one instance of mislabeling was found in 17 of the 29 types of seafood collected.

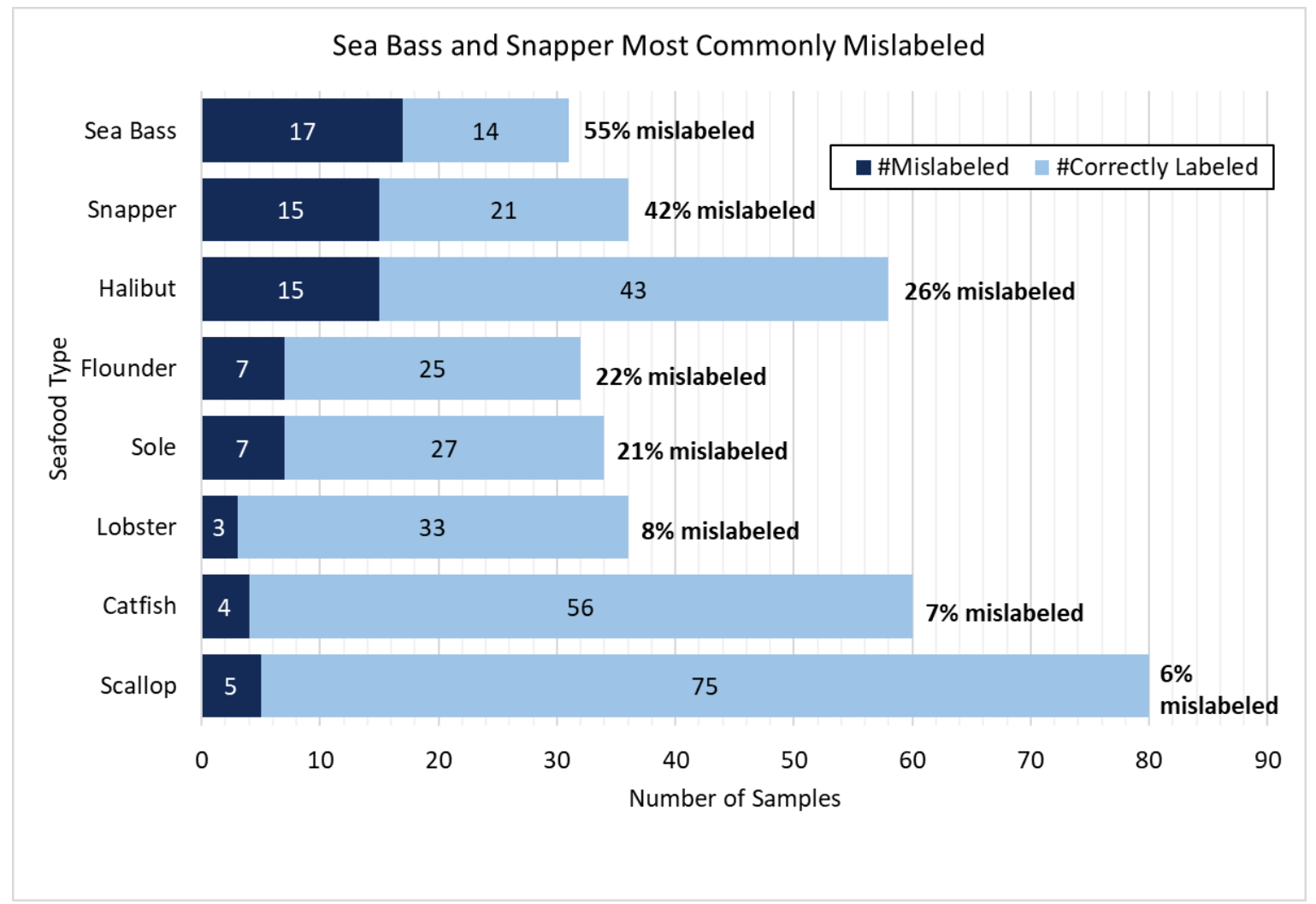

Figure 2. Mislabeling levels (\%) among the most commonly sampled seafood types in our study. 


\section{OCEANA}

\section{Highlights}

\section{Economic Impacts}

The U.S. imports approximately 90 percent of the seafood it consumes and was the largest importer of seafood products by value in 2016. ${ }^{9,10}$ Some of this imported seafood may be sold as local species, fooling consumers into thinking their seafood is from their local waters.

Oceana successfully analyzed 66 samples from the Great Lakes region, which included Illinois, Michigan, Minnesota and Wisconsin. Overall, 27 percent (18/66) of samples from this region were labeled as something other than what consumers ordered. Among the mislabeled samples uncovered in the region, five that were labeled as local Great Lakes species were found to be species that could only be caught in waters from the other side of the world.

Walleye (Sander vitreus) is a freshwater fish with a range that reaches across North America, from the Arctic to the Mississippi River basin. ${ }^{11}$ In the Great Lakes, walleye is historically popular among both commercial and recreational fishers. Yellow perch (Perca flavescens), also commonly referred to as "perch" or "lake perch," is likewise found only in North American freshwaters and is important to the Great Lakes economy. ${ }^{12}$ Michigan Sea Grant estimates the overall value of commercial and recreational fisheries in the region to be $\$ 4-7$ billion annually. ${ }^{13}$

Zander (Sander lucioperca), a freshwater species from European and Asian countries, ${ }^{14}$ was sold as local walleye in Chicago, as well as local perch and walleye in Michigan. Zander swapped for yellow perch was also uncovered by others in a 2018 seafood fraud study in Michigan grocery stores. ${ }^{15}$ In addition, two lake perch samples from Chicago were substituted with Eurasian perch (Perca fluviatilis), a freshwater species native to Europe and introduced to parts of Asia, Australia and Africa. ${ }^{16}$ According to the FDA Seafood List, the only species allowed to be labeled as "lake perch" is the Great Lakes yellow perch (Perca flavescens).

Oceana found other instances of imported species sold as locally important fish in other parts of the country. Two Florida samples labeled as hogfish were substituted with imported seafood, one with the cheaper Asian catfish or pangasius (Pangasianodon hypophthalmus) and the other with spinycheek grouper (Epinephelus diacanthus), a species found only in the Indian Ocean. ${ }^{17}$ In cases like these, consumers think they are buying a local fish fresh off the boat, but what they actually receive is something that was imported and sometimes farmed.

\section{Conservation Risks}

Destructive and illegal fishing practices continue to threaten the sustainability of wild species targeted in the lucrative global seafood sector. Unfortunately, the statuses of many commercially valuable species have not been evaluated, ${ }^{18}$ leaving conservation-minded seafood consumers with few tools to help them make sustainable choices. Consistent with other studies, Oceana continues to find vulnerable species mislabeled as ones with healthier populations and fewer environmental impacts. ${ }^{2,19-21}$

One in $4(15 / 58)$ halibut samples that Oceana tested were mislabeled, slightly higher than the rate of mislabeled halibut found in Oceana's 2013 survey (19 percent, 16/85). ${ }^{3}$ One-third (8/24) of all 


\section{OCEANA}

samples labeled as "Pacific" or "Alaskan" halibut (Hippoglossus stenolepis) were substituted with Atlantic halibut (Hippoglossus hippoglossus), a species listed as endangered on the International Union for the Conservation of Nature's (IUCN) Red List of Threatened Species, and one to "avoid," according to Monterey Bay Aquarium's Seafood Watch. ${ }^{22,23}$ Only 1 of the 7 "Atlantic" halibut samples tested was substituted with Pacific halibut.

Atlantic halibut populations on the East Coast of the U.S. and Canada crashed in the midtwentieth century and have since been slowly rebuilding. ${ }^{24}$ Despite the stark difference in conservation status that remains between the two halibut species, U.S. Pacific halibut fishers on the West Coast are struggling to compete with the influx of Canadian Atlantic halibut entering the U.S. seafood market, which has grown by roughly 60 percent since $2012 .{ }^{25}$

In addition to halibut-for-halibut substitutions, 4 out of 12 (33 percent) halibut samples collected from the West Coast region were substituted with California flounder (Paralichthys californicus), sometimes referred to by the vernacular name "California halibut." In 2017, a local CBS station in the San Francisco Bay Area found 1 of 16 samples tested and sold as halibut to be California flounder. ${ }^{26}$ According to Seafood Watch, California flounder can be a best choice, a good alternative or a fish to avoid depending on where and how it was caught. For example, California flounder caught in Mexico are considered unsustainably fished and stocks from Southern California are depleted, according to the most recent 2011 stock assessment. ${ }^{27,28}$ From the information provided, consumers thought they were getting halibut and instead were sold a fish that could be an overfished species.

Halibut continues to be a seafood type prone to species substitutions, putting depleted Atlantic halibut populations at greater risk and undermining honest Pacific halibut fishermen. More precise species-level labeling across the supply chain is needed to ensure that these speciesspecific differences are communicated to the consumer.

\section{Generic Naming Muddies the Waters}

Seafood labels often use vague market names, which do not reveal the true identity of the fish and mask species-specific differences in health risk and conservation status. ${ }^{29,30}$ In addition, federal regulations allow many of the most commonly sold seafood types to be labeled under umbrella market names that cover numerous species. For instance, according to the FDA, 58 different species of fish can be sold under the acceptable market name of "snapper." Forty-one percent (199/487) of all samples (including samples not successfully analyzed) collected for this study were labeled with generic names.

Twelve of the 19 (63 percent) samples labeled with the generic name "sea bass" or "seabass" were mislabeled. While 19 different species can be labeled "sea bass" or "seabass," according to the FDA guidance, the mislabeled species found in this study were outside of this group. Four of those samples were substituted with Patagonian toothfish (Dissostichus eleginoides) and one with Antarctic toothfish (Dissostichus mawsoni). Sellers of both types of toothfish persuaded the FDA to allow the fish to be marketed under the name "Chilean seabass," ${ }^{30,31}$ even though the species are not sea bass at all, and some populations may be subject to illegal fishing and overexploitation. ${ }^{32-34}$ Despite the name change, Oceana's results show that both species of toothfish are still being sold under the generic name "sea bass," without using "Chilean," which misleads consumers. 


\section{OCEANA}

Two samples from different restaurants in Washington, D.C. were labeled as "royal sea bass" (a name that does not exist in the FDA Seafood List), but were found to be meagre (Argyrosomus regius), a type of croaker. One sample of "striped sea bass" and one sample of "West African sea bass" were substituted with cheaper farmed tilapia (Oreochromis niloticus).

Generic names, as well as fabricated ones used to boost marketability, can mask species-specific differences in conservation status. Species-specific names need to be adopted throughout the entire seafood supply chain to ensure that honest businesses are not cheated, consumers do not unwittingly purchase illegally caught seafood, and buyers know exactly what they are getting.

\section{Catfish Mislabeling}

In this first nationwide investigation of domestic catfish mislabeling, Oceana found 7 percent of the 60 tested samples to be mislabeled. These results are similar to the 9 percent mislabeling rate found in a 2016 study of 80 catfish sold in California. ${ }^{35}$ However, 95 percent of Oceana's samples were generically labeled as simply "catfish." This generic labeling has economic and public health implications-problems that could be mitigated by both full-chain traceability and more specific labeling.

Channel catfish are an economically important species, especially in the southeastern United States where they are farmed. ${ }^{36}$ Due to cheaper catfish family imports from Asia (i.e. pangasius) flooding the U.S. market, the government enacted labeling and inspection policies specific to catfish. ${ }^{37,38}$ These measures include reserving the name "catfish" only for the species farmed in the U.S. (primarily channel catfish), requiring other non-catfish names for Asian pangasius (e.g. basa, tra, swai), and creating more stringent inspection requirements. ${ }^{38,39}$

Monterey Bay Aquarium's Seafood Watch assigns farmed channel catfish from China a red "avoid" distinction due to environmental impacts of the growing operations, unsafe levels of antibiotics and chemicals, and poor oversight. ${ }^{40}$ Government inspections of Asian catfish, such as pangasius, continue to uncover banned chemicals as recently as $2016 .{ }^{41}$ Consumers cannot make informed purchasing decisions when the product is simply labeled "catfish," with no other sourcing information provided.

Whether consumers want to support the domestic farmed catfish industry or avoid unsafe and environmentally damaging imports from overseas, they need information about the species of catfish they are buying, as well as where the fish was farmed. That information should follow the fish from the boat or farm to the final point of purchase.

\section{Discussion and Recommendations}

Oceana applauds the U.S. government for implementing SIMP, but problems with mislabeling persist for species not covered by the program. Oceana found instances where regionally important seafood types that bring revenue to local communities were substituted with imported species from across the globe. Substitutions like these mislead consumers into thinking they are supporting local fisheries.

This seafood bait and switch also means consumers may be receiving lower-value fish than what they think they purchased, or they could be unwittingly supporting illegal or unsustainable fishing 


\section{OCEANA}

and farming practices. Further, mislabeling can also undermine honest fishermen and seafood businesses who play by the rules.

This study also reveals that generic names continue to mislead and confuse seafood consumers. Allowing vague market names facilitates mislabeling, prevents consumers from knowing exactly what they are getting, and results in meaningless labels for seafood types like sea bass, which include many different species with wide-ranging conservation statuses.

Oceana recommends that all seafood-both domestic and imported-must be tracked from the fishing boat or farm to the plate. Consumers should be provided with more information about the seafood they purchase including what specific species it is, where it was caught and how it was caught, or if it was farmed. Seafood traceability, paired with stronger seafood labeling requirements, is the only way U.S. consumers can be sure that all of their seafood is safe, legally caught and honestly labeled.

\section{Acknowledgements}

Oceana would like to thank all the staff, interns and volunteers who collected samples for the study and improved the report, particularly Megan Jordan, Dustin Cranor, Nancy Pyne and the Oceana field team, Alicia Cate, Dr. Kathryn Matthews and Jacqueline Savitz. Sincere thanks to Dr. Kiho Kim of American University for generously sharing lab space and equipment, and Drs. Dana D. Miller and Stefano Mariani for their helpful reviews of the report. 


\section{OCEANA}

\section{References}

1. Kearns M (2018) Americans eating a lot more seafood, according to NFI's new Top 10 list. Seafood Source. Available: https://www.seafoodsource.com/news/supply-trade/americanseating-a-lot-more-seafood-according-to-nfi-s-new-top-10-

list?utm_source =marketo\&utm_medium $=$ email\&utm_campaign=newsletter\&utm_content $=\mathrm{n}$ ewsletter\&mkt_tok=eyJpljoiTWpCa01UTTBaR1V3WIRZNCIsInQiOiJyQXZCbWp6QnBGR FJIM2dLRFIIVkREK2NEcWhNcTIOR2RpeGVjZFpqaOhHUWIvSTVodHNPelR2WGJVWEZa VkZHZEhzYUowUzIYUIF2ODhHa1VsMlwvaVwvZmhBbHBwT2ZJMOdvb1NDQWhrSVJZ Q1MyVVwvblFoaDBkdjQ3QmZWMkpXMiJ9. Accessed Dec 13, 2018.

2. Warner K, Mustain P, Lowell B, Geren S and Talmage S Deceptive Dishes: Seafood Swaps Found Worldwide. Oceana. 22p.

3. Warner K, Timme W, Lowell B and Hirschfield M (2013) Oceana study reveals seafood fraud nationwide. Oceana. 69p.

4. -- (2014) Presidential Memorandum -- Comprehensive Framework to Combat Illegal, Unreported, and Unregulated Fishing and Seafood Fraud. In: whitehouse.gov. Available: https://obamawhitehouse.archives.gov/the-press-office/2014/06/17/presidentialmemorandum-comprehensive-framework-combat-illegal-unreporte. Accessed Sep 27, 2018.

5. -- (2017) Final Rule to Implement U.S. Seafood Import Monitoring Program RIN 0648-BF09. National Oceanic and Atmospheric Administration.

6. FDA (2018) The Seafood List: The FDA's Guide to Acceptable Market Names for Seafood Sold in Interstate Commerce. Available: http://www.accessdata.fda.gov/scripts/SEARCH_SEAFOOD/index.cfm. Accessed Feb 14, 2018.

7. Warner K, Timme W and Lowell B (2012) Widespread Seafood Fraud Found in New York City. Oceana. 17p.

8. -- (May 24, 2013) Mandatory Country of Origin Labeling of Beef, Pork, Lamb, Chicken, Goat Meat, Wild and Farm-Raised Fish and Shellfish, Perishable Agricultural Commodities, Peanuts, Pecans, Ginseng, and Macadamia Nuts. 7CFR

9. Morris S (2017) Imported Seafood Safety: FDA and USDA Could Strengthen Efforts to Prevent Unsafe Drug Residues. United States Government Accountability Office. Report No.: GAO-17-443.

10. National Marine Fisheries Service (2018) Fisheries of the United States, 2017 Report. NOAA. 143p.

11. -- Walleye. In: U.S. Fish \& Wildlife Service. Available: https://www.fws.gov/fisheries/freshwater-fish-of-america/walleye.html. Accessed Dec 12, 2018.

12. -- Yellow perch. In: U.S. Fish \& Wildlife Service. Available: https://www.fws.gov/fisheries/freshwater-fish-of-america/yellow_perch.html. Accessed Dec 12, 2018.

13. -- (2012) Fisheries. In: Michigan Sea Grant. Available: http://www.miseagrant.umich.edu/explore/fisheries/. Accessed Dec 12, 2018.

14. Freyhof J and Kottelat M (2008) Perca fluviatilis. The IUCN Red List of Threatened Species doi: T16580A6135168

15. Conrad B (2018) Biology students present research, Brown wins award. In: Hillsdale Collegian.

16. Freyhof J and Kottelat M (2008) Sander lucioperca. The IUCN Red List of Threatened Species. 


\section{OCEANA}

17. Nair R (2018) Spinycheek Grouper. The IUCN Red List of Threatened Species doi: T132777A46629928

18. Costello C, Ovando D, Clavelle T, et al. (2016) Global fishery prospects under contrasting management regimes. Proceedings of the National Academy of Sciences 113: 5125-5129. doi: 10.1073/pnas.1520420113

19. Logan CA, Alter SE, Haupt AJ, Tomalty K and Palumbi SR (2008) An impediment to consumer choice: Overfished species are sold as Pacific red snapper. Biological Conservation 141: 15911599. doi: 10.1016/j.biocon.2008.04.007

20. Marko PB, Lee SC, Rice AM, et al. (2004) Fisheries: mislabelling of a depleted reef fish. Nature 430: 309-10. doi: 10.1038/430309b

21. Cawthorn D-M, Baillie C and Mariani S (2018) Generic names and mislabeling conceal high species diversity in global fisheries markets. Conservation Letters: e12573. doi: 10.1111/conl.12573

22. Sobel J (1996) Hippoglossus hippoglossus. IUCN Red List of Threatened Species doi: T10097A3162182

23. Monterey Bay Aquarium (2016) Seafood Watch Report: Atlantic flatfish. Monterey Bay Aquarium. 182p.

24. -- (2012) Atlantic Halibut: Hippoglossus hippoglossus. Safina Center. 14p.

25. Bolton A (2018) Alaskan fishermen aren't the only ones noticing the rise of Atlantic halibut. KBBI. Available: https://www.kbbi.org/post/alaskan-fishermen-arent-only-ones-noticingrise-atlantic-halibut. Accessed Dec 13, 2018.

26. Steimle S and Sterling A (2017) Testing Shows Many Bay Area Restaurants Mislabel Fish "CBS San Francisco. CBS SF Bay Area. Available: https://sanfrancisco.cbslocal.com/2017/04/27/testing-shows-many-bay-area-restaurantsmislabeling-fish/. Accessed Dec 27, 2018.

27. Monterey Bay Aquarium (2018) Seafood Watch California flounder and Cortez halibut. Mexico: Pacific and Gulf of California. Monterey Bay Aquarium. 66p.

28. -- (2011) Stock Assessment Summary for California Halibut. California Department of Fish and Wildlife. 9p.

29. Lowell B, Mustain P, Ortenzi K and Warner K (2015) One Name, One Fish: Why Seafood Names Matter. Oceana. 12p.

30. Jacquet $J L$ and Pauly D (2008) Trade secrets: Renaming and mislabeling of seafood. Marine Policy 32: 309-318. doi: 10.1016/j.marpol.2007.06.007

31. -- (2013) US FDA recognises all toothfish as Chilean Seabass. In: COLTO - Coalition of Legal Toothfish Operators. Available: http://www.colto.org/2013/08/05/5-august-2013-us-fdarecognises-all-toothfish-as-chilean-seabass/. Accessed Jan 4, 2019.

32. Knecht GB (2006) Hooked: Pirates, Poaching and the Perfect Fish. New York: Rodale.

33. Hobart N (2010) Report of the Twenty-Ninth Meeting of the Scientific Committee. Scientific Committee for the Conservation of Antarctic Marine Living Resources. 426p.

34. Engdal E and Saeter K (2018) Catching Thunder: The True Story of the World's Longest Sea Chase. London, UK: Zed Books.

35. Bosko SA, Foley DM and Hellberg RS (2018) Species substitution and country of origin mislabeling of catfish products on the U.S. commercial market. Aquaculture 495: 715-720. doi: 10.1016/j.aquaculture.2018.06.052

36. U.S. Department of Agriculture (2018) Catfish Production. 6p. Report No.: ISSN: 1948-271X.

37. Becker E (2002) Delta Farmers Want Copyright on Catfish. New York Times. Available: https://www.nytimes.com/2002/01/16/us/delta-farmers-want-copyright-oncatfish.html?rref=collection\%2Ftimestopic\%2FFarm\%20Bill\%20(U.S.). Accessed Dec 18, 2018. 


\section{DCEANA}

38. -- (2015) Mandatory Inspection of Fish of the Order Siluriformes and Products Derived From Such Fish. 80 Fed Reg: 75589.

39. United States Government Accountability Office (2012) SEAFOOD SAFETY: Responsibility for Inspecting Catfish Should Not Be Assigned to USDA. Report No.: GAO-12-411.

40. Monterey Bay Aquarium (2017) Seafood Watch Report - Channel Catfish: China. 65p.

41. Fried K and Woodall P (2016) Curious Catfish Shipments Highlight Need to Stop the TPP. In: Food \& Water Watch.

42. Handy SM, Deeds JR, Ivanova NV, et al. (2011) A single-laboratory validated method for the generation of DNA barcodes for the identification of fish for regulatory compliance. Journal of AOAC International 94: 201-210. 


\section{OCEANA}

\section{APPENDICES}

Appendix A - Imported Seafood Types Covered under SIMP

- Abalone

- Atlantic Cod

- Blue Crab (Atlantic)

- Dolphinfish (Mahi Mahi)

- Grouper

- King Crab (red)

- Pacific Cod

- Red Snapper

- Sea Cucumber

- Sharks

- Shrimp

- Swordfish

- Tunas (Albacore, Bigeye, Skipjack, Yellowfin, and Bluefin)

\section{Appendix B - Supplemental Methods}

Oceana staff and 76 volunteers collected 487 seafood samples which were preserved through desiccation on silica beads prior to submission to laboratories for DNA testing. Four hundred and forty-nine of those samples were successfully analyzed for species identity by three different laboratories. All finfish samples were analyzed at the Canadian Center for DNA Barcoding at the University Guelph in Canada using a technique that involves extracting a short DNA sequence from a gene found in all animals and comparing it to a catalogue of more than 15,000 fish species. DNA barcoding is also the method used by FDA to monitor misbranding of seafood. ${ }^{42}$ Lobster and crab samples were submitted to Applied Food Technologies, a commercial laboratory in Florida and mostly analyzed via DNA barcoding and results compared against a taxonomically validated database for shellfish. Scallop samples were also analyzed via DNA barcoding at Conservation X Labs in Washington. DNA species identity results from all labs were compared to how the seafood was labeled as sold and judged mislabeled if the identity did not match the FDA acceptable market name for that species, as determined by the 2018 FDA Seafood List. ${ }^{6}$ 


\section{OCEANA}

\section{Appendix C - List of mislabeled seafood samples with collection location}

${ }^{*} \mathrm{R}=$ restaurant; $\mathrm{G}=$ grocery store $(\mathrm{COOL}$ requirements); $\mathrm{M}=$ market

${ }^{1}$ Unique common names are also legal market names

${ }^{2}$ States included in each region for analysis:

- $\quad$ Northeast $=$ MA, ME, NH, RI

- Mid Atlantic = DC, DE, MD, NY, VA

- Southeast = FL, GA, LA, MS, NC, SC

- Inland Areas = CO, IL, KS, MI, MN, MO, WI

- West Coast $=$ CA, OR, WA

\begin{tabular}{|c|c|c|c|c|c|c|}
\hline $\begin{array}{c}\text { Fish Type } \\
\text { (\#mislabeled/\#total) }\end{array}$ & Sold As & Identified As & $\begin{array}{c}\text { Unique Common Name }{ }^{1} \\
\text { (FDA Acceptable Market Name) }\end{array}$ & $\mathrm{R}, \mathrm{G}, \mathrm{M}^{*}$ & City & State $^{2}$ \\
\hline \multirow[t]{2}{*}{ bass $(2 / 6)$} & bass, striped & Morone chrysops (or hybrid) & bass, white (bass) & $\mathrm{R}$ & Tarrytown & NY \\
\hline & bass, striped & Morone saxatilis $x$ Morone chrysops & $\begin{array}{l}\text { bass, palmetto (bass or bass, } \\
\text { hybrid striped or white) }\end{array}$ & $\mathrm{R}$ & Washington & DC \\
\hline \multirow[t]{4}{*}{ catfish $(4 / 60)$} & catfish & Hippoglossoides elassodon & sole, flathead (sole or flathead) & $\mathrm{R}$ & Charleston & SC \\
\hline & catfish & Pangasianodon hypophthalmus & $\begin{array}{l}\text { catfish, sutchi (swai or sutchi or } \\
\text { striped pangasius or tra) }\end{array}$ & $\mathrm{R}$ & Estes Park & $\mathrm{CO}$ \\
\hline & catfish & Pangasianodon hypophthalmus & $\begin{array}{l}\text { catfish, sutchi (swai or sutchi or } \\
\text { striped pangasius or tra) }\end{array}$ & $\mathrm{R}$ & Portland & OR \\
\hline & $\begin{array}{l}\text { catfish, } \\
\text { Chesapeake } \\
\text { Bay }\end{array}$ & Ictalurus punctatus & catfish, channel (catfish) & $\mathrm{R}$ & Lewes & DE \\
\hline $\operatorname{crab}(1 / 1)$ & crab, jonah & Cancer pagurus & crab, edible rock (crab, rock) & G & Natick & MA \\
\hline \multirow[t]{2}{*}{$\operatorname{drum}(3 / 11)$} & drum, black & Archosargus probatocephalus & sheepshead (sheepshead) & $\mathrm{R}$ & New Orleans & LA \\
\hline & redfish & Pogonias cromis & drum, black (drum) & $M$ & Biloxi & MS \\
\hline
\end{tabular}




\section{OCEANA}

\begin{tabular}{|c|c|c|c|c|c|c|}
\hline & redfish & Ictalurus punctatus & catfish, channel (catfish) & $\mathrm{R}$ & Gulfport & MS \\
\hline \multirow[t]{7}{*}{ flounder (7/32) } & $\begin{array}{l}\text { flounder, } \\
\text { summer }\end{array}$ & Paralichthys patagonicus & flounder, Patagonian (flounder) & $M$ & Holden Beach & NC \\
\hline & $\begin{array}{l}\text { flounder, } \\
\text { summer }\end{array}$ & Paralichthys lethostigma & $\begin{array}{l}\text { flounder, southern (flounder or } \\
\text { fluke) }\end{array}$ & $M$ & Holden Beach & NC \\
\hline & $\begin{array}{l}\text { flounder, } \\
\text { summer }\end{array}$ & Paralichthys lethostigma & $\begin{array}{l}\text { flounder, southern (flounder or } \\
\text { fluke) }\end{array}$ & $M$ & Shallotte & NC \\
\hline & $\begin{array}{l}\text { flounder, } \\
\text { summer }\end{array}$ & Lepidopsetta polyxystra & $\begin{array}{l}\text { sole, Northern rock (sole or } \\
\text { flounder) }\end{array}$ & $\mathrm{G}$ & Lewes & DE \\
\hline & $\begin{array}{l}\text { flounder, } \\
\text { summer }\end{array}$ & Paralichthys lethostigma & sole, Southern (sole or flounder) & M & Lewes & $\mathrm{DE}$ \\
\hline & $\begin{array}{l}\text { flounder, } \\
\text { summer }\end{array}$ & Pleuronectes quadrituberculatus & plaice, Alaska (plaice or flounder) & $\mathrm{R}$ & Onancock & VA \\
\hline & $\begin{array}{l}\text { flounder, } \\
\text { summer }\end{array}$ & Psettodes erumei & $\begin{array}{l}\text { halibut, Indian Ocean spiny } \\
\text { (flounder) }\end{array}$ & $\mathrm{R}$ & Norfolk & VA \\
\hline \multirow[t]{8}{*}{ halibut (15/58) } & halibut & Paralichthys californicus & flounder, California (flounder) & G & Los Angeles & CA \\
\hline & halibut & Paralichthys californicus & flounder, California (flounder) & $\mathrm{G}$ & San Diego & CA \\
\hline & halibut & Paralichthys californicus & flounder, California (flounder) & $M$ & Seattle & WA \\
\hline & halibut, Alaska & Hippoglossus hippoglossus & halibut, Atlantic (halibut) & $M$ & Clearwater & $\mathrm{FL}$ \\
\hline & halibut, Alaska & Hippoglossus hippoglossus & halibut, Atlantic (halibut) & $M$ & Chicago & $\mathrm{IL}$ \\
\hline & halibut, Alaska & Hippoglossus hippoglossus & halibut, Atlantic (halibut) & $\mathrm{R}$ & Chicago & $\mathrm{IL}$ \\
\hline & halibut, Alaska & Hippoglossus hippoglossus & halibut, Atlantic (halibut) & $\mathrm{R}$ & Lawrence & $\mathrm{KS}$ \\
\hline & halibut, Alaska & Hippoglossus hippoglossus & halibut, Atlantic (halibut) & $\mathrm{R}$ & Ocean City & MD \\
\hline
\end{tabular}




\section{OCEANA}

\begin{tabular}{|c|c|c|c|c|c|c|}
\hline & halibut, Alaska & Reinhardtius hippoglossoides & $\begin{array}{l}\text { turbot, Greenland (Greenland } \\
\text { turbot) }\end{array}$ & G & Springfield & VA \\
\hline & $\begin{array}{l}\text { halibut, } \\
\text { Atlantic }\end{array}$ & Hippoglossus stenolepis & halibut, Pacific (halibut) & $\mathrm{R}$ & Washington & DC \\
\hline & $\begin{array}{l}\text { halibut, } \\
\text { Atlantic }\end{array}$ & Paralichthys sp. & (flounder) & $\mathrm{R}$ & Estes Park & $\mathrm{CO}$ \\
\hline & $\begin{array}{l}\text { halibut, North } \\
\text { Pacific }\end{array}$ & Hippoglossus hippoglossus & halibut, Atlantic (halibut) & $\mathrm{R}$ & Lewes & $\mathrm{DE}$ \\
\hline & halibut, Pacific & Hippoglossus hippoglossus & halibut, Atlantic (halibut) & $\mathrm{R}$ & Chicago & IL \\
\hline & halibut, Pacific & Hippoglossus hippoglossus & halibut, Atlantic (halibut) & G & Natick & MA \\
\hline & halibut, Pacific & Paralichthys californicus & flounder, California (flounder) & $\mathrm{R}$ & Dana Point & CA \\
\hline hogfish (2/12) & hogfish & Epinephelus diacanthus & grouper, spinycheek (grouper) & $\mathrm{R}$ & Islamorada & $\mathrm{FL}$ \\
\hline & hogfish & Pangasianodon hypophthalmus & $\begin{array}{l}\text { catfish, sutchi (swai or sutchi or } \\
\text { striped pangasius or tra) }\end{array}$ & $\mathrm{R}$ & Key West & $\mathrm{FL}$ \\
\hline jack, striped (1/1) & jack, striped & Pseudocaranx dentex & trevally, white (jack or trevally) & $\mathrm{R}$ & Washington & DC \\
\hline lobster (3/36) & lobster & Panulirus argus & $\begin{array}{l}\text { lobster, Caribbean spiny (lobster, } \\
\text { spiny) }\end{array}$ & $\mathrm{R}$ & Savannah & GA \\
\hline & lobster & Panulirus argus & $\begin{array}{l}\text { lobster, Caribbean spiny (lobster, } \\
\text { spiny) }\end{array}$ & $\mathrm{R}$ & $\begin{array}{l}\text { Virginia } \\
\text { Beach }\end{array}$ & VA \\
\hline & lobster, slipper & Macrobrachium rosenbergii & $\begin{array}{l}\text { prawn, giant freshwater (shrimp, } \\
\text { freshwater) }\end{array}$ & $\mathrm{R}$ & Encinitas & CA \\
\hline mackerel (1/4) & $\begin{array}{l}\text { mackerel, } \\
\text { Spanish }\end{array}$ & Scomber scombrus & mackerel, Atlantic (mackerel) & $\mathrm{R}$ & $\begin{array}{l}\text { Virginia } \\
\text { Beach }\end{array}$ & VA \\
\hline $\operatorname{perch}(3 / 6)$ & perch & Sander lucioperca & zander (zander or pikeperch) & $\mathrm{R}$ & Elk Rapids & MI \\
\hline & perch, lake & Perca fluviatilis & perch, Eurasian (perch) & $\mathrm{R}$ & Chicago & $\mathrm{IL}$ \\
\hline
\end{tabular}




\section{OCEANA}

\begin{tabular}{|c|c|c|c|c|c|c|}
\hline & perch, lake & Perca fluviatilis & perch, Eurasian (perch) & $\mathrm{R}$ & Chicago & IL \\
\hline \multirow[t]{5}{*}{ rockfish (5/5) } & rockfish & Morone saxatilis x Morone chrysops & $\begin{array}{l}\text { bass, palmetto (bass or bass, } \\
\text { hybrid striped or white) }\end{array}$ & $\mathrm{R}$ & Washington & $\mathrm{DC}$ \\
\hline & rockfish & Morone saxatilis & bass, striped (bass) & M & Washington & $\mathrm{DC}$ \\
\hline & rockfish & Morone saxatilis & bass, striped (bass) & $\mathrm{R}$ & Washington & DC \\
\hline & rockfish & Morone sp. & & $\mathrm{R}$ & Washington & DC \\
\hline & rockfish & Morone saxatilis & bass, striped (bass) & $\mathrm{R}$ & St. Michaels & MD \\
\hline \multirow[t]{5}{*}{ scallop (5/80) } & scallop, bay & Placopecten magellanicus & scallop, sea (scallop) & $\mathrm{R}$ & Key West & $\mathrm{FL}$ \\
\hline & $\begin{array}{l}\text { scallop, } \\
\text { Patagonian }\end{array}$ & Placopecten magellanicus & scallop, sea (scallop) & $\mathrm{G}$ & $\begin{array}{l}\text { Wilton } \\
\text { Manors }\end{array}$ & $\mathrm{FL}$ \\
\hline & scallop, sea & Patinopecten yessoensis & $\begin{array}{l}\text { scallop, common Japanese } \\
\text { (scallop) }\end{array}$ & M & $\begin{array}{l}\text { Jacksonville } \\
\text { Beach }\end{array}$ & $\mathrm{FL}$ \\
\hline & scallop, sea & Patinopecten yessoensis & $\begin{array}{l}\text { scallop, common Japanese } \\
\text { (scallop) }\end{array}$ & $\mathrm{G}$ & Atlanta & GA \\
\hline & scallop, sea & Chlamys farreri & $\begin{array}{l}\text { scallop, Farrer's (not in FDA } \\
\text { Seafood List) }\end{array}$ & $\mathrm{G}$ & $\begin{array}{l}\text { Saint } \\
\text { Petersburg }\end{array}$ & $\mathrm{FL}$ \\
\hline \multirow[t]{5}{*}{ sea bass (17/31) } & sea bass & Dissostichus mawsoni & $\begin{array}{l}\text { toothfish, Antarctic (toothfish or } \\
\text { Chilean seabass) }\end{array}$ & $\mathrm{G}$ & Chula Vista & CA \\
\hline & sea bass & Morone saxatilis x Morone chrysops & $\begin{array}{l}\text { bass, palmetto (bass or bass, } \\
\text { hybrid striped or white) }\end{array}$ & $\mathrm{R}$ & Washington & DC \\
\hline & sea bass & Lates calcarifer & perch, giant (barramundi) & $\mathrm{R}$ & Encinitas & CA \\
\hline & sea bass & Oreochromis niloticus & tilapia, Nile (tilapia) & $\mathrm{R}$ & Minneapolis & $\mathrm{MN}$ \\
\hline & sea bass & Dissostichus eleginoides & $\begin{array}{l}\text { toothfish, Patagonian (toothfish } \\
\text { or Chilean seabass) }\end{array}$ & $\mathrm{R}$ & Jacksonville & $\mathrm{FL}$ \\
\hline
\end{tabular}




\section{OCEANA}

\begin{tabular}{|c|c|c|c|c|c|c|}
\hline & sea bass & Lates calcarifer & perch, giant (barramundi) & $\mathrm{R}$ & New York & NY \\
\hline & sea bass & Dissostichus eleginoides & $\begin{array}{l}\text { toothfish, Patagonian (toothfish } \\
\text { or Chilean seabass) }\end{array}$ & G & Los Angeles & CA \\
\hline & sea bass & Dissostichus eleginoides & $\begin{array}{l}\text { toothfish, Patagonian (toothfish } \\
\text { or Chilean seabass) }\end{array}$ & G & Minnetonka & $\mathrm{MN}$ \\
\hline & sea bass & Dissostichus eleginoides & $\begin{array}{l}\text { toothfish, Patagonian (toothfish } \\
\text { or Chilean seabass) }\end{array}$ & G & Seattle & WA \\
\hline & sea bass & Morone sp. & & $\mathrm{R}$ & Chicago & IL \\
\hline & $\begin{array}{l}\text { sea bass, } \\
\text { branzino }\end{array}$ & Morone saxatilis $x$ Morone chrysops & $\begin{array}{l}\text { bass, palmetto (bass or bass, } \\
\text { hybrid striped or white) }\end{array}$ & $\mathrm{R}$ & Washington & DC \\
\hline & $\begin{array}{l}\text { sea bass, } \\
\text { California }\end{array}$ & Morone saxatilis & bass, striped (bass) & $\mathrm{R}$ & Chicago & IL \\
\hline & $\begin{array}{l}\text { sea bass } \\
\text { (Patagonian } \\
\text { toothfish) }\end{array}$ & Dissostichus mawsoni & $\begin{array}{l}\text { toothfish, Antarctic (toothfish or } \\
\text { Chilean seabass) }\end{array}$ & G & Dana Point & CA \\
\hline & sea bass, royal & Argyrosomus regius & meagre (croaker or shadefish) & $\mathrm{R}$ & Washington & $\mathrm{DC}$ \\
\hline & sea bass, royal & Argyrosomus regius & meagre (croaker or shadefish) & $\mathrm{R}$ & Washington & $\mathrm{DC}$ \\
\hline & $\begin{array}{l}\text { sea bass, } \\
\text { striped }\end{array}$ & Oreochromis niloticus & tilapia, Nile (tilapia) & $\mathrm{R}$ & Excelsior & $\mathrm{MN}$ \\
\hline & $\begin{array}{l}\text { sea bass, West } \\
\text { African }\end{array}$ & Oreochromis niloticus & tilapia, Nile (tilapia) & $\mathrm{R}$ & Washington & DC \\
\hline snapper $(15 / 36)$ & snapper & Pagrus major & madai (porgy or sea bream) & $\mathrm{R}$ & Washington & $\mathrm{DC}$ \\
\hline & snapper & Psettodes erumei & $\begin{array}{l}\text { halibut, Indian Ocean spiny } \\
\text { (flounder) }\end{array}$ & $\mathrm{R}$ & Biloxi & MS \\
\hline & snapper & Sebastes mystinus & rockfish, blue (rockfish) & $\mathrm{R}$ & Long Beach & CA \\
\hline
\end{tabular}




\section{OCEANA}

\begin{tabular}{|c|c|c|c|c|c|c|}
\hline & snapper & Plagiogeneion rubiginosum & bonnetmouth (bonnetmouth) & G & New Orleans & LA \\
\hline & snapper & Sebastes crameri & rockfish, darkblotched (rockfish) & $\mathrm{R}$ & $\begin{array}{l}\text { San Juan } \\
\text { Capistrano }\end{array}$ & CA \\
\hline & snapper & Sciaenops ocellatus & drum, red (drum or redfish) & $\mathrm{R}$ & Biloxi & MS \\
\hline & snapper & Oreochromis niloticus & tilapia, Nile (tilapia) & $\mathrm{R}$ & $\begin{array}{l}\text { Virginia } \\
\text { Beach }\end{array}$ & VA \\
\hline & $\begin{array}{l}\text { snapper, } \\
\text { Florida }\end{array}$ & Pristipomoides sieboldii & $\begin{array}{l}\text { jobfish, lavender (jobfish or } \\
\text { snapper) }\end{array}$ & $\mathrm{R}$ & Ocean City & MD \\
\hline & $\begin{array}{l}\text { snapper, } \\
\text { hogfish }\end{array}$ & Lachnolaimus maximus & hogfish (hogfish) & M & $\begin{array}{l}\text { Jacksonville } \\
\text { Beach }\end{array}$ & FL \\
\hline & $\begin{array}{l}\text { snapper, } \\
\text { Japanese }\end{array}$ & Pagrus major & madai (porgy or sea bream) & $\mathrm{R}$ & New York & NY \\
\hline & $\begin{array}{l}\text { snapper, } \\
\text { mangrove }\end{array}$ & Lutjanus griseus & snapper, gray (snapper) & M & $\begin{array}{l}\text { Madeira } \\
\text { Beach }\end{array}$ & $\mathrm{FL}$ \\
\hline & snapper, pink & Etelis coruscans & snapper, yellowstripe (snapper) & M & Chicago & IL \\
\hline & snapper, silk & Lutjanus peru & snapper, Pacific (snapper) & G & San Diego & CA \\
\hline & $\begin{array}{l}\text { snapper, } \\
\text { vermillion, B- } \\
\text { liner }\end{array}$ & Lutjanus campechanus & $\begin{array}{l}\text { snapper, red (snapper or red } \\
\text { snapper) }\end{array}$ & $\mathrm{R}$ & $\begin{array}{l}\text { Neptune } \\
\text { Beach }\end{array}$ & $\mathrm{FL}$ \\
\hline & $\begin{array}{l}\text { snapper, } \\
\text { yellowtail }\end{array}$ & Lutjanus synagris & snapper, lane (snapper) & M & $\begin{array}{l}\text { Saint } \\
\text { Petersburg }\end{array}$ & $\mathrm{FL}$ \\
\hline sole (7/34) & sole, dover & Sander vitreus & walleye (walleye) & G & Minnetonka & MN \\
\hline & sole, lemon & Pseudopleuronectes americanus & blackback (flounder or sole) & M & Maynard & MA \\
\hline & sole, lemon & Pseudopleuronectes americanus & blackback (flounder or sole) & M & Maynard & MA \\
\hline & sole, lemon & Pseudopleuronectes americanus & blackback (flounder or sole) & M & New York & NY \\
\hline
\end{tabular}




\section{OCEANA}

\begin{tabular}{|c|c|c|c|c|c|c|}
\hline & sole, lemon & Paralichthys dentatus & $\begin{array}{l}\text { flounder, summer (flounder or } \\
\text { fluke) }\end{array}$ & $\mathrm{R}$ & Commack & NY \\
\hline & sole, lemon & Hippoglossoides elassodon & sole, flathead (sole or flathead) & G & Chicago & $\mathrm{IL}$ \\
\hline & sole, lemon & Limanda ferruginea & $\begin{array}{l}\text { flounder, yellowtail (flounder or } \\
\text { sole) }\end{array}$ & $\mathrm{M}$ & Chicago & $\mathrm{IL}$ \\
\hline \multirow[t]{3}{*}{ walleye (3/14) } & walleye & Coregonus clupeaformis & whitefish, lake (whitefish) & $\mathrm{R}$ & Grand Rapids & MI \\
\hline & walleye & Sander lucioperca & zander (zander or pikeperch) & $\mathrm{R}$ & Elk Rapids & MI \\
\hline & walleye, pike & Sander lucioperca & zander (zander or pikeperch) & $\mathrm{R}$ & Chicago & $\mathrm{IL}$ \\
\hline
\end{tabular}

